International Review of Research in Open and Distributed Learning Volume 17, Number 4

June- 2016

\title{
An Empirical Study of Factors Driving the Adoption of Mobile Learning in Omani Higher Education
}

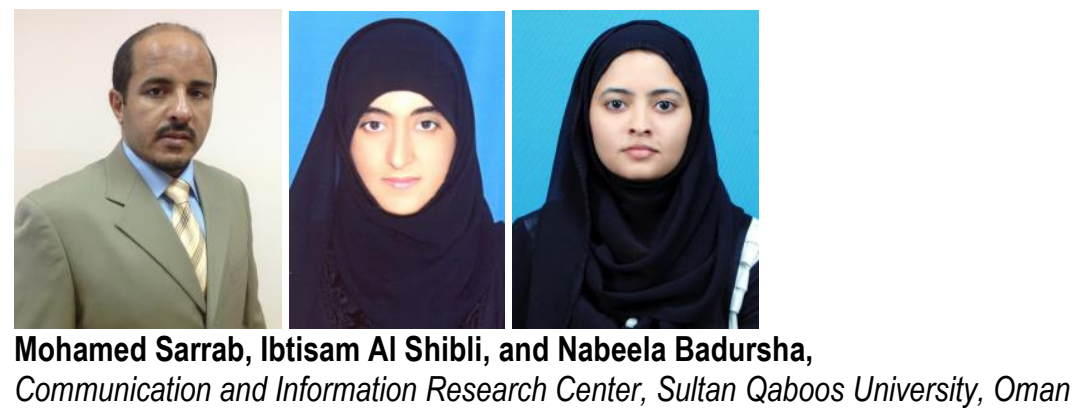

\begin{abstract}
Mobile learning (M-learning) provides a new learning channel in which learners can access content and just in time information as required irrespective of the time and location. Even though M-learning is fast evolving in many regions of the world, research addressing the driving factors of M-learning adoption is in short supply. This article focuses on the driving factors in adoption of M-learning and the learner's perceptions and willingness towards M-learning adoption. Technology Acceptance Model (TAM) has been shown to be a valid and powerful model in mobile and other learning technologies research. Based on Technology Acceptance Model theory, this paper analyzes the influencing factors on M-learning adoption and measure the acceptance of M-learning in Oman. The data collected from 806 participants in 17 different Omani higher education institutions using a survey questionnaire. Some factors of perceived innovative characteristics, such as ease of use, usefulness, enjoyment, suitability, social, and economic were found to have more influence on learners' adoption of M-learning which help to facilitate and promote future empirical research. This effort is part of funded research project that investigate the development, adoption, and dissemination of M-learning in Oman.
\end{abstract}

Keywords: mobile learning, M-learning, adoption factors, higher education

\section{Introduction}

The idea of using M-learning in educational and instructional technology field has dramatically evolved in the last decade. With growing acceptance of mobile devices, it is important that adequate learning and 
educational approaches are developed in order to utilize the benefits of mobile devices effectively for an enhanced learning. M-learning is defined as learning delivered across multiple contexts through social and content interactions, using handheld and mobile technologies such as personal digital assistants (PDAs), smartphones, or other mobile devices (Sarrab, 2014; Sha, Look, Chen, \& Zhang , 2012). Mlearning increases learning flexibility by adapting learning to be more personalized and learner-centered. M-learning can be supported in formal as well as informal settings. The mobility and flexibility features offered by mobile devices enable knowledge building by learners in different contexts. A wellimplemented M-learning application can assist in saving the cognitive load by filtering accessible information based on all contextual factors (Chao, Lai, Chen, \& Huang, 2013; Sarrab, Elbasir, \& Alnaeli, 2016).

Despite the rapid growth of M-learning technology, there is a lack of research data addressing the factors that drives M-learning adoption. The learner's perception and acceptance of M-learning has to be investigated before adopting the technology. Therefore, it is essential to conduct research that identifies the driving factors of M-learning adoption. Various techniques are available for deriving the factors for acceptance of M-learning. User's acceptance of M-learning is the vital part in the development of a successful M-learning application. Therefore, there is a need to explore the factors that have to be considered while application development. The most important factor to be considered in the development phase of M-learning is mobility. It enables users to be in contact even outside the reach of conventional communication spaces (Sarrab, Alzahrani, Alalwan, \& Alfarraj, 2014; Yao-Ting, Kuo-En, \& Tzu-Chien, 2016).

In this context, the research study was carried out using Technology Acceptance Model (TAM) as a theoretical framework for university students' acceptance of M-learning and its intention of use. TAM is one of the most widely used theories in studying the adoption of IT innovations and new information systems. The core objectives of the study are:

- To derive factors which affect M-learning adoption in Oman.

- To measure the acceptance of M-learning in Oman.

\section{Related Work}

\section{M-Learning}

Instructors are enforced to use modern information technology tools as learners become more Information and Communication Technology (ICT) savvy through what is called E-learning that employ the networked communications systems which utilize the advantage of modern information technology to carry out the learning process using computer-based learning, virtual classroom, Web-based learning, digital collaboration and other learning technologies. The lack of flexibility in E-learning approach lead to M-learning utilizing the innovative technologies offered by recent portable and mobile devices (Ciampa, 2014; Isaiah \& Martin, 2015; Moore, 2011). M-learning is a new and independent part of E-learning 
(Florence \& Jeffrey, 2013). M-learning in higher education is still in the early stages of development (Park, 2011).

The main concern of M-learning approach is to offer anywhere and any-time learning opportunity. Which can be achieved using different mobile devices, for example, personal digital assistants (PDAs), smartphones, and tablet computers (Sarrab, 2015; Uzunboylu \& Ozdamli, 2011).

Generally, M-learning can be defined as "any educational provision where the sole or dominant technologies are handheld or palmtop devices (Park, Nam, \& Cha, 2012). With the growing popularity of mobile devices usage in education, there is a need for research that focuses on how learners adopt Mlearning and the factors those drive its acceptance (Liu, 2008; Tsai, Tsai, \& Hwang, 2012). Moreover, impelled by the growing market of various mobile technologies, M-learning has grown in to more widely accepted solutions in educational environments (Sarrab, Al-Shih, \& Rehman, 2013). User's acceptance is the vital part in the deployment of M-learning solution (Liu et al, 2010) as M-learning allow users to customize their contents according to their needs offering more flexibility in learning process. However, it has been widely recognized that M-learning is not just about the use of mobile devices in the learning process but also about learning across contexts (Walker, 2006). Winters (2006) reconcept M-learning to address the mediated learning via mobile technology.

\section{M-Learning in Middle East}

In the Middle East, E-learning is seen to be very promising both to corporations and educational institutions. Mobile devices have revolutionized communication and entertainment systems of today's world. But the educational benefits of mobile devices remains unexplored predominantly in the educationally less advanced countries of the Middle East (Khan, Al-Shihi, Al-Khanjari, \& Sarrab, 2015). There are only few countries that could employ mobile devices in learning environment quite effectively. These countries include South Korea, USA, Japan, Taiwan, Malaysia, Singapore, Australia, and European Union as well. The educationally advanced countries have developed strong policies and strategies for handling the $21^{\text {st }}$ century educational need. These strategies are not effectively explored in Middle East. There are four major catalysts in the emergence of M-learning market in Middle East which includes: consumer demand for M-learning apps, large-scale deployments of tablets in the educational sectors, nationwide content digitization efforts across the academic institutions in the region, and the rapid adoption of M-learning in the higher education sectors (Romani, 2009; Sarrab \& Elgamel, 2013).

According to the International Telecommunication Union (ITU), the Middle East has some of the highest mobile penetration rates in the world. With the growing number of mobile devices in Middle East, mobile connectivity is very important for internet connectivity. This is evident for Information Technology Authority of Oman, that the country has more than $150 \%$ of mobile penetration rate per inhabitant for mobile internet services. Hence, every Omani organization, school, business, home, and office has access to the World Wide Web. Most importantly, they will be able to use such internet accessibility with mobile technologies interact, transact, and gain the required of knowledge. In Oman, one of the key driving factors of mobile connectivity popularity is that the traditional landline options are simply unavailable or are prohibitively inconvenient to access in many regions in the country. Therefore, wireless technologies is the main internet infrastructure. The internet operators provide $3 \mathrm{G}$ and $4 \mathrm{G}$ networks and have 
launched 4G Long Term Evolution (LTE) services as well (Information Technology Authority, 2013). In spite of a considerable mobile and network penetration, several findings in the Middle East region have revealed that stakeholder lacks awareness and potential benefits related to M-learning. The lack of awareness among stakeholders about the positive educational value that mobile phones can add, and a generalized conservatism toward the use of mobile phones by young people, also serve as inhibiting factors for adoption of M-learning in these countries (Isaacs, 2012). However, some countries in Middle East are taking initiatives for introducing M-learning to their educational system, for example Saudi government has initiated projects for distance and M-learning JUSUR (a Learning Management System), Saudi Digital Library. The Qassim College of Medicine is known to be the first higher education college in Saudi Arabia, providing M-learning.

M-learning infrastructure of a country depends upon the national telecommunications and information infrastructure. The educational institution must have proper infrastructure for a proper deployment of Mlearning solutions (Khan et al., 2015). M-learning providers in educationally less developed countries of Middle East are less focused on the learners' characteristics and styles. Most of the available contents are un-organized as well as non-instructional. In Saudi Arabia, M-learning face the problems of customized contents. For example, a study at King Khalid University, revealed that the interference between learning and non-learning materials on social media.

\section{Intrinsic of M-Learning Drivers}

The ideas and concepts of M-learning started to become popular in different education sectors and learning environments. M-learning helps to reduce the traditional training infrastructure and simplifies the learning process. It enhances a new dimension for learner-instructor interaction thus improving the accessibility, interoperability, and reusability of educational resources and a positive attitude among the learners towards learning (Manoj \& Jayesh, 2014). Despite the tremendous potential, there are a number of factors driving M-learning adoption. In order to deliver adequate M-learning services, it is essential to examine the learner's adoption process of M-learning (Liu, 2008). The key factors for the success of Mlearning depends on the user's willingness and cognitive engagement in M-learning activities. There are technical and non-technical constraints in M-learning adoptions. The technical constraints include communication infrastructure, software application and content customization while the non-technical consists of operational feasibility, trust, awareness, training, cultural norms and financial support (Liu et al., 2010).

Based on previous researches on M-learning adoption, various roles of M-learning users are considered when adopting M-learning services, namely technology user, consumer, instructor and learner. The adoption of M-learning solution has been intensively studied by researchers in which the Technology Acceptance Model (TAM) is one of the most widely accepted and applied models. Two theories, namely subjective task value and readiness for online learning, are integrated with TAM in combination with two influencing factors - perceived usefulness and perceived ease of use, in order to develop an advanced conceptual model (Liu, 2008). 


\section{Theoretical Background}

Technology Acceptance Model (TAM) is one of the well-known models related to acceptance of technologies which was originally proposed by Davis in 1986. The concept of TAM is to provide a theoretical basis to describe behavioral intentions attitude toward use, external variables impact, internal beliefs and the usage of actual system (Legris, Ingham, \& Collerette, 2003). Based on Ajzen and Fishbein (1980) TAM is an extension model of Theory of Reasoned Action (TRA). TAM is proposed to be a model of user acceptance of information technology by adapting TRA Davis (1989) and Davis, Bagozzi, and Warshaw (1989). TAM adapts this belief attitude intention behavior relationship and further hypothesizes that two influencing factors (perceived ease of use and perceived usefulness) are the key factors leading to user acceptance of information technology (Zhao \& Zhu, 2010). TAM also proposed that external factors affect actual and intention use through mediated effects on perceived ease of use and perceived usefulness (Davis, 1989). Perceived ease of use refers to the degree to which prospective user expects that using a particular service would be free of effort while perceived usefulness is defined as the degree to which an individual perceives that using a particular system would enhance their performance (Davis, 1989). Further, perceived ease of use is supposed to influence perceived usefulness, which directly affects attitude and intention as well as willingness. Figure 1 shows the proposed research model.

\section{Influencing Factors (Research Model)}

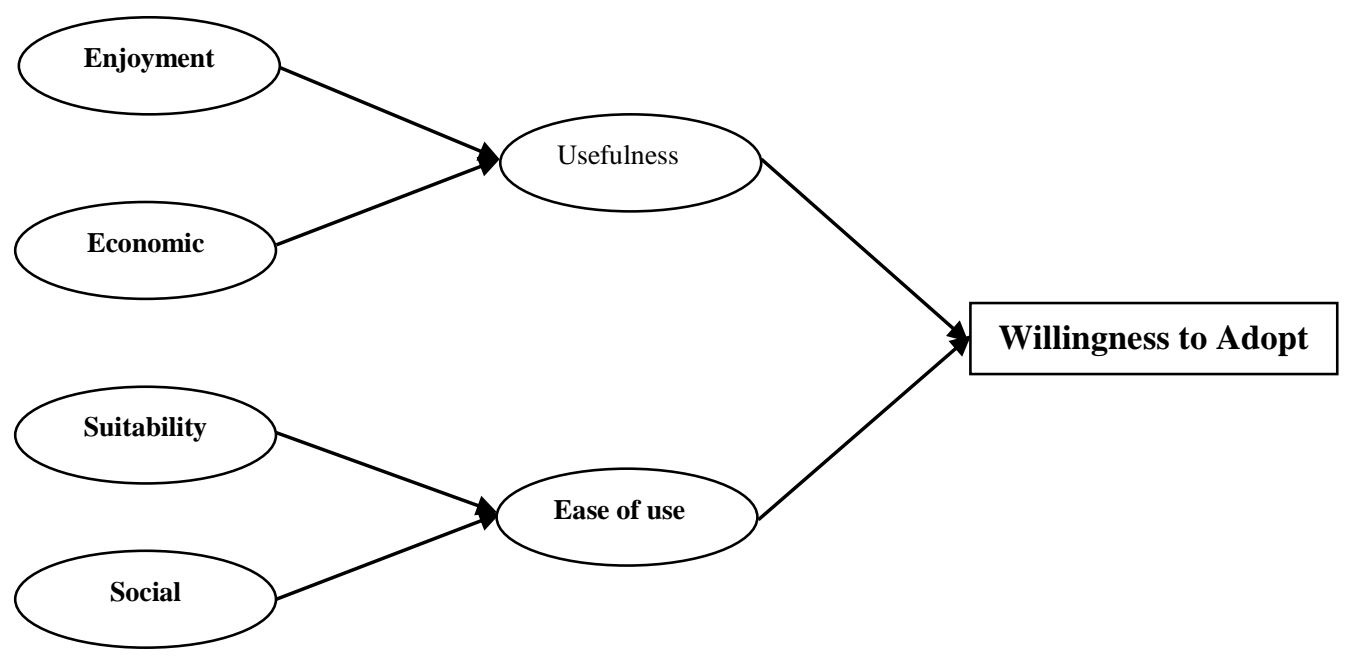

Figure 1. Research model.

According to TAM, ease of use and perceived usefulness are most important determinants of actual system use. These two factors are influenced by external variables. The main external factors are social factors, cultural factors, and political factors. Social factors include language, skills, and enabling conditions (Almasri, 2014). Political factors are mainly the impact of using technology in politics and political crisis. The attitude to use is concerned with the user's evaluation of the desirability of employing 
a particular information system application. Behavioral intention is the measure of the prospect of a person employing the application (Zhao \& Zhu, 2010).

\section{Perceived Usefulness}

"Perceived usefulness was found to have significant impacts on the willingness to adopt any technology" (Chau, 1996). Perceived usefulness has been proposed or validated to be an important motivator for the acceptance of a number of technological innovations (e.g., Jiang, Hsu. Klein \& Lin,, 2000). In M-learning perceived usefulness is defined as "the learners' perception that the task will be useful to meet some future goal" (Cole, Bergin, \& Whittaker, 2008). Eccles and Wigfield in 2002 stated that learners may adopt a learning activity since it facilitates the attainment of important future goals, although they lack interest in the learning activity (Eccles \& Wigfield, 2002). Concerning educational IT innovations, such as web-based learning, utility value is also found to be a substantial factor impacting learners' intentions (Chiu, Sun, Sun, \& Ju, 2007). "Chiu and Wang in 2008 indicated that improving learning performance, effectiveness and productivity represent learners perceived performance expectancy.” (Chiu \& Wang, 2008).

The proposed model considers the influence of two external variables of perceived usefulness which are enjoyment and economic. Enjoyment refers to the felt when using mobile devices for learning (Andrew, 2011; Sarrab, Alzahrani, Alalwan, \& Alfarraj, 2015) and economic refers to M-learning solution that predicts the learner's economic behavior (Andreea \& Cristina, 2012; Sarrab, Alzahrani, Alalwan, \& Alfarraj, 2015).

It is essential to include a construct of perceived usefulness in TAM to explain the adoption of educational IS innovations. Instead of offering instant rewards, educational IS innovations, such as M-learning tend to benefit learners in the future and in the long term. When it complies with their future goals, students would be more likely to accept M-learning. This increases a positive feeling of near-term usefulness.

\section{Perceived Ease of Use}

Perceived ease of use issues have been considered as an important factor affecting M-learning adoption. Perceived ease of use refers to the degree to which the user expects that using a particular service would be free of effort. In 2009, Wang, Wu, and Wang stated that there are several challenges facing M-learning, such as connectivity, limited processing power, and reduced input capabilities along with many possible technological restrictions impeding M-learning adoption, such as small screen size and poor screen resolution. The proposed model considers the influence of perceived ease of use in respect of two external variables including suitability of using mobile devices in learning (Economides \& Nikolaou, 2008; Sarrab, Alzahrani, Alalwan, \& Alfarraj, 2015) and social use of mobile devices and social media produces personalized M-learning (Claudia, 2013; Economides \& Nikolaou, 2008; Sarrab, Alzahrani, Alalwan, \& Alfarraj, 2015). In TAM, perceived ease of use is found to be significant behavior predictor of perceived usefulness and behavioral intention (Legris et al., 2003; Li, Qi, \& Shu, 2008); perceived ease of use is found to be a significant predictor of perceived to behavioral of willingness to adopt M-learning.

\section{Research Methodology}


The study commenced with a focused literature review on key concepts from the following areas: technology adoption and diffusion, learning management systems, E-learning, and M-learning. The aim was to highlight E-learning adoption factors and issues and specifically, M-learning. Several adoption factors were highlighted, as well as technical and non-technical issues were considered. The issues were investigated as likely inhibitors to adoption. At this stage, factors and issues were refined and combined to produce 12 distinctive factors. A pilot survey instrument was developed with sets of questions for each factor following Likert scale $(1-5)$. The aim was to validate the accuracy and consistency of the factors and their corresponding questions statements from the point of view of teachers and students. More than 850 online and hard copy survey questionnaires were distributed with a response rate of about $95 \%$ was achieved. Intially, the data validation showed low accuracy/consistency for more than half of the questions and factors, subsequently, only six factors were chosen to develop the M-learning acceptance measure, as follows:

- Ease of use of mobile devices in accessing learning contents anywhere (Davis, 1989).

- $\quad$ Suitability of using mobile devices in learning (Economides \& Nikolaou, 2008).

- Enjoyment felt when using mobile devices for learning (Huang, Hsiao, Tang \& Lien, 2014).

- Usefulness of using mobile devices in learning on society in general and the relationship between teachers and students in specific (Davis, 1989).

- Economic M-learning as an economic learning approach provides a solution that predicts the learner's economic behavior (Andreea, 2011).

- Social using mobile devices and social media produces personalized M-learning (Claudia, 2013; Economides \& Nikolaou, 2008).

\section{Survey Instrument and Sample}

As most of the current M-learning services are focused on university students, they accordingly became the target group of the study. The sample was collected from undergraduate students in all over Sultanate of Oman colleges and universities. Students and faculties were invited to participate and complete the questionnaire. A brief seminar of survey purposed, talking about scope of the study, objectives, problem of M-learning, and other point's related to same topic was given.

A total of 806 responses were collected. The respondents consisted of $39.6 \%$ males and $60.4 \%$ females. Ages ranged between 23-29 had a response percentage of over half at 59.9\%. The descriptive statistics of the sample are shown in Table 1 . Among the respondents, $47.4 \%$ are using smart phones for internet access and about $35.6 \%$ are using mobile devices for more than 4 hours daily.

Table 1

Demographic Information of Study Participants

Demographic Profile $\quad$ Percent (\%)


Gender

Male

$39.6 \%$

Female

$60.4 \%$

Age Range (in year)

18-23

$59.8 \%$

24-29

$11.6 \%$

30-35

$7.3 \%$

$36-41$

$10.8 \%$

42-47

$4.8 \%$

$48+$

$5.7 \%$

Devices used most for internet accessing

Desktop/ PC

$17.5 \%$

Laptop

$31.5 \%$

Smart phone

$47.4 \%$

Tablet

$2.9 \%$

Other

$0.8 \%$

Period of time using mobile devices

Less than 1 hour daily

$7 \%$

1-2hours daily

$29.5 \%$

3-4 hours daily

$26.5 \%$

More than 4 hours daily

$35.6 \%$

Other

$1.4 \%$

\section{Data Analysis and Results}

Table 2 showed the measurement model including the question items and extracted factors values and Table 3 presents the correlation matrix and discriminant assessment of the selected factors Principal components extraction with Varimax rotation was first conducted to extract five factors using SPSS 23 . The results show that all items fit their respective factors quite well. All the factor loadings are above the threshold of .7. As described in Table 2, the Cronbach's alpha values range from .716 to .0.8649, which are all over the .7 level. Confirmative factor analysis was then conducted using AMOS 7.0. The composite reliability values (CR) and average extracted variance (AVE) of all the constructs satisfy the recommended level of .8 and .5 respectively, thereby indicating good internal consistency (Fornell \& Larcker, 1981).

Table 2

\section{The Measurement Model}

\begin{tabular}{|c|c|c|c|c|c|c|c|c|c|}
\hline \multirow{2}{*}{ Item } & \multicolumn{6}{|c|}{ Factors Extracted } & \multirow{2}{*}{$\begin{array}{l}\text { Cronbach's } \\
\text { alpha }\end{array}$} & \multirow[t]{2}{*}{ CR } & \multirow[t]{2}{*}{ AVE } \\
\hline & 1 & 2 & 3 & 4 & 5 & 6 & & & \\
\hline Q241 & .737 & .116 & .336 & -.003 & .164 & .031 & 0.846 & 0.843 & 0.478 \\
\hline
\end{tabular}




\begin{tabular}{|c|c|c|c|c|c|c|c|c|c|}
\hline Q242 & .750 & .119 & .307 & -.068 & .123 & .060 & & & \\
\hline Q243 & .645 & .171 & . 189 & .127 & .056 & .179 & & & \\
\hline Q244 & .724 & .073 & .115 & .197 & .048 & .082 & & & \\
\hline Q245 & .728 & .104 & -.024 & .244 & .079 & -.003 & & & \\
\hline Q246 & .620 & .250 & -.029 & .266 & .062 & .066 & & & \\
\hline Q258 & .059 & .003 & .160 & .095 & .210 & .673 & & & \\
\hline Q259 & .031 & .121 & .066 & .026 & .161 & .820 & 0.716 & 0.729 & 0.477 \\
\hline Q2510 & .186 & .209 & .109 & .134 & .041 & .777 & & & \\
\hline Q271 & .198 & .216 & .385 & .543 & .252 & .116 & & & \\
\hline Q272 & .146 & .106 & .106 & .752 & .138 & .107 & & 0706 & 0406 \\
\hline Q273 & .204 & .192 & .219 & .743 & .166 & .072 & 0.7927 & 0.790 & 0.490 \\
\hline Q274 & .158 & 188 & .333 & .591 & .003 & .062 & & & \\
\hline Q281 & .272 & .200 & .743 & .253 & .169 & .101 & & & \\
\hline Q282 & .197 & .179 & .728 & .289 & .145 & .160 & 0.8639 & 0.867 & 0.686 \\
\hline Q283 & .206 & .159 & 692 & .249 & .102 & 198 & & & \\
\hline Q301 & .167 & .129 & .161 & .131 & .773 & .086 & & & \\
\hline Q302 & .008 & .165 & .092 & .060 & .762 & .252 & 0.7307 & 0.731 & 0.476 \\
\hline Q303 & .196 & .180 & 122 & 193 & .666 & .130 & & & \\
\hline Q311 & .084 & .571 & .437 & .106 & .311 & .049 & & & \\
\hline Q312 & .096 & .625 & .394 & .128 & .202 & .098 & & & \\
\hline Q314 & .157 & .678 & .273 & .077 & .154 & .130 & 0.8277 & 0.828 & 0.491 \\
\hline Q315 & .220 & .777 & .079 & .143 & .090 & .130 & & & \\
\hline Q316 & .215 & .717 & -.047 & .267 & .082 & .070 & & & \\
\hline
\end{tabular}

Table 3

Correlation Matrix and Discriminant Assessment

\begin{tabular}{lllllllll}
\hline Variable & Mean & SD & Usefulness & $\begin{array}{l}\text { Ease of } \\
\text { Use }\end{array}$ & Suitability & Enjoyment & Economic & Social \\
\hline Usefulness & 3.5246 & 0.9696 & 0.828 & & & & & \\
Ease of & 3.1803 & 1.0667 & 0.584 & 0.692 & & & & \\
Use & & & & & & & \\
Suitability & 3.2437 & 1.1355 & 0.453 & 0.359 & 0.691 & & & \\
Enjoyment & 3.6565 & 0.9901 & 0.733 & 0.571 & 0.439 & 0.704 & & \\
Economic & 3.3203 & 1.0473 & 0.566 & 0.451 & 0.533 & 0.582 & 0.69 & 0.701 \\
Social & 3.5989 & 1.0216 & 0.671 & 0.545 & 0.477 & 0.684 & 0.633 & \\
\hline
\end{tabular}

Table 4 shows the model fit indices that determines how well proposed model fits the collected data that aims to provide the most fundamental indication of how well the proposed theoretical framework fits the sample data. Included in this category are the Goodness-of-fit statistic (GFI) with recommended value $<0.9$ and obtained value 0.891 and the adjusted goodness-of-fit statistic (AGFI) with obtained value 
0,862, Normed-fit index (NFI) with obtained value 0,882 , Comparative fit index (CFI) has value 0.903 which revised from FNI. In both NFI and CFI values for this statistic range between o.o and 1.0 with values closer to 1.0 indicating good fit, Tucker-Lewis Index (TLI) has obtained 0.887 and finally the Root mean square error of approximation (RMSEA) has obtained o.o66.

Table 4

Model Fit Indices

\begin{tabular}{lllllll}
\hline Model fit indices & GFI & AGFI & NFI & CFI & TLI & RMSEA \\
\hline Recommended & & & & & & \\
value & $<.9$ & $>.8$ & $>.9$ & $>.9$ & $>.9$ & $>.08$ \\
Obtained & 0.891 & 0.862 & 0.882 & 0.903 & 0.887 & 0.066 \\
\hline
\end{tabular}

\section{General Discussion}

Based on the study findings, it was revealed that about $90 \%$ of study participators were keen interest and willingness to adopt M-learning and use mobile devices in learning process. The study initial findings on the demographic section indicated that more than half $60.4 \%$ of the study participators were female and $39.6 \%$ were male. Most of the participators were from young generation where $59.8 \%$ were aged between 18-23 and the remaining 40\% were distributed between different age groups as was shown in Table 1 . The $47.7 \%$ majority of study participants use smart phones for internet accessing followed by $31.5 \%$ of participants using laptops to obtain information from the internet and about $20 \%$ of respondents using other types of machines to access internet. The responses indicate that more than $95 \%$ use their mobile devices for more than one hour per day. Finally, it can be discovered that more than $90 \%$ of the study participants are enthusiast and willing to use mobile devices as a learning tool.

The results of this study can provide insight into what factors need to be considered for designing an Mlearning system. This research adds to the existing literature on user's acceptance and intention to adopt M-learning. Understanding the factors affecting M-learning will help the stakeholders to incorporate these factors in their design and implementation of M-learning initiatives.

\section{Conclusion}

M-learning has the potential to become an effective solution for providing education along with traditional methods. It is important to motivate learners about the benefits of using M-learning for higher education. The ease of use and usefulness of M-learning systems can add value to the existing learning management system through an advancement in learning process and enhancing the learner's acceptance towards M-learning. This research offers useful information in understanding the influencing factors on M-learning adoption and its acceptance in Oman. This study used Technology Acceptance Model (TAM) as a theoretical framework to examine the driving factors related to M-learning adoption. According to 
TAM, perceived usefulness and perceived ease of use had a significant positive effect on user's adoption of M-learning systems. Furthermore, the findings reveal that ease of use, usefulness, enjoyment, suitability, social, and economic contributed significantly towards adoption of M-learning.

There is a need to motivate instructors, increase their awareness of using M-learning, and provide them with adequate training. The quality of service offered by M-learning systems needs to include userfriendliness, meeting of all user needs, and conversant service as this will attract more users to Mlearning. In conclusion, the results indicated that there is a need to develop strategic plans and provide guidelines considering learners acceptance in order to include all critical driving factors for the sustainable deployment of M-learning.

\section{Limitation and Implications for Future Studies}

The rapid increase of mobile applications has outpaced the traditional software applications. However, these traditional software engineering applications cannot be applied directly in mobile devices due to the following issues:

- Different mobile platforms such as iOS, Android, Windows 7, etc.

- Different hardware makers for platforms such as HTC, Google, Samsung, Apple, etc.

- Mobile device user interfaces (UI) which provide a new mechanism for human computer interaction sequences such as multi-touch interfaces, image recognition, code scanning, etc., that have not been previously explored in research and there is no existing established user interface guidelines.

The main future concerns and challenges of M-learning adoption are as follows:

- M-learning may make it easier to fraud. M-learning users may use dishonest methods to take or copy something valuable from another person, this may make it easier to cheat.

- Finding the best infrastructures by choosing the right infrastructure that supports the needed mobile application operations.

- Creating universal M-learning system user interface. Means designing for diversity in end-users and contexts of use of M-learning system interface.

- Design an effective context aware M-learning application that can sense the environment and react or adapt to the changing context while learner's learning process.

- The wireless network trust ability. M-learning learners can employ mobile device and wireless network to get suitability, simplicity, and immediacy of M-learning in a proper response time and accessing appropriate learning content. 
- Disclosing of the learner information via network. There should be a kind of privacy policy that enforces network not to disclose any learners information, unless their consent has been granted.

- Feeling of isolation, separation, or of being out-of-the-loop. The freedom offered by M-learning opens up opportunities for learner to work alone and isolated from other learners.

- Cross platform. M-learning system should be platform independent, where, learners can connect irrespective of their used devices, or platforms, for example, Android, iOS, Windows, or Blackberry.

\section{Recommendations}

In an epoch where humanistic values are diminishing and vision towards social progress is disintegrating, our need to promote responsible education and learning is more crucial than ever. The advent of mobile phones presents a great opportunity and offers a timely challenge to re-define and transform our educational paradigms. As wine fans claim, we cannot pour fresh wine in old bottles, likewise, M-learning too requires a new philosophical framework and new educational paradigms if it is to flourish. Only then will it become ubiquitous. Hence, below are some recommendations for the learning system policymakers:

a. Leverage existing investments. Policy-makers should take stock of existing ICT investments and approaches to devise strategies that complement rather than replace the current infrastructure.

b. Localize policies. Policy-makers should consider the local contexts of the country or region when creating new policies or adapting existing ones, as strategies that work for one country may not be appropriate in another.

c. Support open technical standards. Policy-makers should encourage the use of open, standardsbased platforms for M-learning applications, to increase access and streamline the development process.

d. Promote intersectional cooperation and multi-stakeholder partnerships. Policy-makers should promote cooperation between different branches of government and encourage partnerships between stakeholders from a variety of sectors and levels.

e. Establish policies at all levels. Policy-makers should create or revise M-learning policies at both the national and local levels, regardless of whether education is decentralized. National policies should provide overarching structure and guidance, while local policies direct implementation in individual districts or institutions.

f. Review and update existing policies. Policy-makers should revisit existing policies, particularly at the local level, that may be overly restrictive in regard to the use of mobile technology at schools and universities. National policies may need to be clarified or revised to give better guidance to districts and institutions. 
g. Ensure inclusive education. Policy-makers should ensure that M-learning policies promote gender equality and accessibility for learners with disabilities. This effort is essential to meet Education for All (EFA) goals of providing quality education to all learners worldwide. ICT is a powerful vehicle for enhancing learning, and mobile devices form an essential part of this vehicle. If current ICT strategies for education begin to include mobile devices along with digital learning materials, support for teachers, and guidelines on best practices, M-learning will soon become an important part of education (Mehdipour \& Hamideh, 2013).

\section{Acknowledgment}

This article is based upon research work funded by The Research Council (TRC) of the Sultanate of Oman, under Grant No: ORG/SQU/ICT/13/oo6, (www.trc.gov.om).

\section{References}

Ajzen, I., \& Fishbein, M. (1980). Understanding attitudes and predicting social behavior. Englewood Cliffs, NJ: Prentice-Hall.

Almasri, A.K., (2014). The influence on mobile learning based on technology acceptance model (Tam), mobile readiness $(\mathrm{Mr})$ and perceived interaction ( $\mathrm{Pi}$ ) for higher education students. International Journal of Technical Research and Applications, 2(1), 5-11.

Andreea, M., \& Cristina, H. (2012). Mobile learning: An economic approach. In G. Sabine, L. Fuhua, Rory, M. Kinshuk (Eds.), Intelligent and adaptive learning systems: Technology enhanced support for learners and teachers. (311-326). USA: Information Science References (an imprinted of IGI Global).

Chao, H. C, Lai, C. F., Chen, S. Y., \& Huang, Y. M. (2013). A M-learning content recommendation service by exploiting mobile social interactions. IEEE Transactions on Learning Technologies, 7(3), 221230.

Chau, P. Y. (1996). An empirical assessment of a modified technology acceptance model. Journal of Management Information Systems, 13(2), 185-204.

Chiu, C. M., \& Wang, E. T. (2008). Understanding web-based learning continuance intention: The role of 
subjective task value. Information \& Management, 45(3), 194-201.

Chiu, C. M., Sun, S. Y., Sun, P. C., \& Ju, T. L. (2007). An empirical analysis of the antecedents of webbased learning continuance. Computers \& Education, 49(4), 1224-1245.

Ciampa, K. (2014). Learning in a mobile age: An investigation of student motivation, Journal of Computer Assisted Learning, 30(1), 82-96.

Claudia, D. W, (2013). New forms of learning for vocational education: Mobile learning-social learninggame-based learning. Berufsbildung in Wissenschaft und Praxis - BWP BWP Special Edition. 2730.

Cole, J. S., Bergin, D. A., \& Whittaker, T. A. (2008). Predicting student achievement for low stakes tests with effort and task value. Contemporary Educational Psychology, 33(4), 609-624

Davis, F. D., Bagozzi, R. P., \& Warshaw, P. R. (1989). User acceptance of computer technology: A comparison of two theoretical models. Management Science, 35(8), 982-1003.

Davis, F.D. (1989). Perceived usefulness, perceived ease of use, and user acceptance of information technology. MIS Quarterly, 13(3), 319-340.

Dawn, S \& Andrew, K. (2011). An Analysis of Mobile Learning in Education, Business, and Medicine. In K. Andrew (Ed.). Models for interdisciplinary mobile learning: Delivering information to students. (1-25). USA: Information Science References (an imprinted of IGI Global).

Eccles, J. S., \& Wigfield, A. (2002). Motivational beliefs, values, and goals. Annual Review of Psychology, 53(1), 109-132.

Economides, A.A., \& Nikolaou, N. (2008). Evaluation of handheld devices for mobile learning. International Journal of Engineering Education (IJEE), 24(1), 3-13.

Florence, M., \& Jeffrey, E. (2013). Here and now mobile learning: An experimental study on the use of mobile technology, Computers \& Education, 68, 76-85

Fornell, C., \& Larcker, D.F. (1981). Evaluating structural equation models with unobservable variables and measurement error. Journal of marketing research, 18(1), 39-50.

Haung, J. H., Lin, Y. R., \& Chuang, S.T. (2007). Elucidating user behavior of mobile learning: A perspective of the extended technology acceptance model. The Electronic Library, 25, 585-598.

Huang, R. T., Hsiao, C. H., Tang, T. W., \& Lien, T. C. (2014). Exploring the moderating role of perceived flexibility advantages in mobile learning continuance intention (MLCI). The International Review of Research in Open and Distance Learning, 15(3), 140-157.

Isaacs, S. (2012). Turning on mobile learning in Africa and the Middle East: Illustrative initiatives and policy implications. UNESCO Working Paper Series on Mobile Learning (ISSN 2227- 


\section{9). Paris, France. UNESCO.}

Isaiah, T. A., \& Martin, C. (2015). Using management procedure gaps to enhance e-learning implementation in Africa. Computers \& Education, 90, 64-79.

ITA Information Technology Authority. (2013). Sultanate of Oman progress report on the information society 2003-2013. Muscat Oman, 1-30.

Jiang, J. J., Hsu. M. K., Klein. G., \& Lin, B. (2000). E-Commerce user behavior model: An empirical study. Human Systems Management, 19(4), 265-276.

Khan, A.I., Al-Shihi, H. I, Al-Khanjari, Z.A., \& Sarrab, M. K. (2015). Mobile learning (M-Learning) adoption in the Middle East: Lessons learned from the educationally advanced countries. Telematics and Informatics, 32(4), 909-920.

Legris, P., Ingham, J., \& Collerette, P. (2003). Why do people use information technology? A critical review of the technology acceptance model. Information \& Management, 4O(3), 191-204.

Li, Y. Q., Qi, J. Y., \& Shu, H. Y. (2008). Review of relationships among variables in TAM. Tsinghua Science \& Technology, 13(3), 273-278.

Liu, Y. (2008). An adoption model for mobile learning. In Proceeding for the IADIS International Conference e-Commerce. Amsterdam, The Netherlands.

Liu, Y., Han, S., \& Li, H. (2010). Understanding the factors driving m-learning adoption: A literature review. Campus-Wide Information Systems, 27(4), 210-226.

Manoj, P., \& Jayesh, M. P. (2014). The factors influencing in mobile learning adoption: A literature review. International Journal of Application or Innovation in Engineering \& Management (IJAIEM), 3(9), 133-138.

Mehdipour, Y., \& Hamideh. Z. (2013). Mobile learning for education: Benefits and challenges. International Journal of Computational Engineering Research, 3(6), 93-101.

Moore, J. L. Camille, D., \& Krista, G. (2011). e-Learning, online learning, and distance learning environments: Are they the same? Internet and Higher Education, 14, 129-135

Park, Y. S., Nam, M. W., \& Cha, S. B. (2012). University students' behavioral intention to use mobile learning: Evaluating the technology acceptance model. British Journal of Educational Technology, 43(4), 592-605.

Park. Y. (2011). A pedagogical framework for mobile learning: Categorizing educational applications of mobile technologies into four types. International Review of Research in Open and Distance Learning, 12(2), 78-102.

Romani, V. (2009). The politics of higher education in the Middle East: Problems and prospects. Middle 
East Brief, Brandeis University, 36(1), 1-8.

Sarrab, M. K, Al-Shih, H. I., \& Rehman, O. M. (2013). Exploring major challenges and benefits of mlearning adoption. British Journal of Applied Science \& Technology, 3(4), 826-839.

Sarrab, M. K. (2014). M-learning in education: Omani Undergraduate Students Perspective, International Educational Technology Conference (IETC-2014), September $3^{\text {th }}-5^{\text {th }}$, Chicago, USA.

Sarrab, M. K., \& Elgamel, L. E. (2013). Contextual M-learning system for higher education providers in Oman. World Applied Sciences Journal, 22(10), 1412-1419.

Sarrab, M. K., Alzahrani, A. A., Alalwan, N. A., \& Alfarraj, O. M. (2014). From T-learning into M-learning in education at the University Level: Undergraduate Students Perspective. International Journal of Mobile Learning and Organisation, 8(3/4), 167-186.

Sarrab, M. K., Alzahrani, A. A., Alalwan, N. A., \& Alfarraj, O. M. (2015). An empirical study on cloud computing requirements for better mobile learning services. International Journal of Mobile Learning and Organisation, 9(1), 1-20.

Sarrab, M. K., Elbasir, M. H., \& Alnaeli, S. M. (2016). Towards a quality model of technical aspects for mobile learning services: An empirical investigation. Computers in Human Behavior, 55(A), 100112.

Sha, L., Look, C. K, Chen, W., \& Zhang, B. H. (2012). Understanding mobile learning from the perspective of self-regulated learning, Journal of Computer Assisted Learning, 28(4), 366-378.

Tsai, P. S., Tsai, C. C., \& Hwang, G. J. (2012). Developing a survey for assessing preferences in constructivist context-aware ubiquitous learning environments. Journal of Computer Assisted Learning, 28(3), 250-264.

Uzunboylu, H., \& Ozdamli, F. (2011). Teacher perception for m-learning: Scale development and teachers' perceptions. Journal of Computer Assisted Learning, 27(6), 544-556.

Walker, K. (2006). Introduction: Mapping the landscape of mobile learning. In M. Sharples (Ed.), Big issues in mobile learning: Report of a workshop by the kaleidoscope network of excellence mobile learning initiative. University of Nottingham, UK.

Wang, Y. S., Wu, M. C., \& Wang, H. Y. (2009). Investigating the determinants and age and gender differences in the acceptance of mobile learning. British Journal of Educational Technology, $40(1), 92-118$.

Winters, N. (2006). What is mobile learning? In M. Sharples (Ed.), Big issues in mobile learning: Report of a workshop by the kaleidoscope network of excellence mobile learning initiative. University of Nottingham, UK. 
Yao-Ting, S., Kuo-En, C., \& Tzu-Chien, L. (2016). The effects of integrating mobile devices with teaching and learning on students' learning performance: A meta-analysis and research synthesis.

Computers \& Education, 94, 252-275.

Zhao, Y., \& Zhu, Q., (2010), Influence factors of technology acceptance model in mobile learning. Fourth International Conference on Genetic and Evolutionary Computing (ICGEC), 542-545.

\section{Appendix}

Table 5

An Empirical Study Survey Items

\begin{tabular}{|c|c|}
\hline Demographic Background & \\
\hline Gender & Male, Female \\
\hline Age range (in years). & $18-23,24-29,30-35,36-41,42-47,48+$ \\
\hline $\begin{array}{l}\text { Highest completed level of } \\
\text { education }\end{array}$ & Higher Secondary, Diploma, Bachelor, Masters , Ph.D., Other \\
\hline Profile & Full time, Part time, Teacher, Other \\
\hline Income range (in R.O) & $\begin{array}{l}\text { No income, Less than } 251,251-500,501-750,751-1000,1001-1250,1251- \\
1500,1501+\end{array}$ \\
\hline \multicolumn{2}{|l|}{ Internet Experience } \\
\hline Internet usage & Yes, No \\
\hline $\begin{array}{l}\text { Devices used for internet } \\
\text { accessing }\end{array}$ & Desktop/ PC, Laptop, Smart phones, Tablets, Other \\
\hline $\begin{array}{l}\text { How long (internet access } \\
\text { time) }\end{array}$ & $\begin{array}{l}\text { Less than } 1 \text { hour daily, 1-2hours daily, 3-4 hours daily, More than } 4 \text { hours } \\
\text { daily, Other }\end{array}$ \\
\hline $\begin{array}{l}\text { Tasks accomplished using the } \\
\text { internet }\end{array}$ & $\begin{array}{l}\text { Searching information, Taking quiz, Playing games, Watching Videos } \\
\text { online, Video conferencing, Downloading, Uploading, Chatting, } \\
\text { Communication and Social networking }\end{array}$ \\
\hline \multicolumn{2}{|l|}{ E-learning Experience } \\
\hline E-learning Usage & Yes, No \\
\hline $\begin{array}{l}\text { How long (the use of } \mathrm{E}- \\
\text { learning) }\end{array}$ & $\begin{array}{l}\text { Less than } 1 \text { hour daily, 1-2hours daily, 3-4 hours daily, More than } 4 \text { hours } \\
\text { daily, Other }\end{array}$ \\
\hline $\begin{array}{l}\text { Tasks accomplished in E- } \\
\text { learning }\end{array}$ & $\begin{array}{l}\text { Downloading learning contents, Uploading learning contents, Reading E - } \\
\text { books, Preparation of learning materials, Assignment preparation, Taking } \\
\text { mock test, Communication with colleagues and teachers, }\end{array}$ \\
\hline Major issues in E-learning & $\begin{array}{l}\text { Not available all the time, not available everywhere, Not available all the } \\
\text { time and Not available everywhere and others. }\end{array}$ \\
\hline \multicolumn{2}{|l|}{ Mobile device experience } \\
\hline Own mobile device & Yes, No \\
\hline Type of mobile device & $\begin{array}{l}\text { Desktop/ PC, Laptop, PDA, Tablets, Smart phones, E-Book reader, All of } \\
\text { them except Desktop/ PC, Other }\end{array}$ \\
\hline Apps used most often on & Limited period free trial (e.g. Verb Ace-Pro Arabic-English Dictionary, \\
\hline
\end{tabular}




\begin{tabular}{|c|c|}
\hline mobile device & $\begin{array}{l}\text { Magic Translator),Open source (WhatsApp, moodle), Purchased (Apps } \\
\text { from Apple store, Apps from android) }\end{array}$ \\
\hline $\begin{array}{l}\text { How long (the use of mobile } \\
\text { device) }\end{array}$ & $\begin{array}{l}\text { Less than } 1 \text { hour daily, 1-2hours daily, 3-4 hours daily, More than } 4 \text { hours } \\
\text { daily, Other }\end{array}$ \\
\hline $\begin{array}{l}\text { Tasks accomplished using } \\
\text { mobile device }\end{array}$ & $\begin{array}{l}\text { Accessing internet, Searching information, Messaging (SMS, MMS), } \\
\text { Recording of video, Taking photographs, Installation of software, As a } \\
\text { calculator, Taking quiz, Playing games, Watching videos, Video } \\
\text { conferencing, Downloading (say games, videos), Uploading (say } \\
\text { documents, ideos), Chatting, Communication (say email) and Social } \\
\text { networking (say face book) }\end{array}$ \\
\hline \multicolumn{2}{|l|}{ Mobile learning experience } \\
\hline $\begin{array}{l}\text { Usage of mobile device for } \\
\text { learning }\end{array}$ & Yes, No \\
\hline $\begin{array}{l}\text { Where do mobile devices } \\
\text { used for academic tasks }\end{array}$ & $\begin{array}{l}\text { School, college campus, home, office, class room, lecture theatre and } \\
\text { other. }\end{array}$ \\
\hline $\begin{array}{l}\text { Motivators behind the use of } \\
\text { mobile device for learning }\end{array}$ & Parents, colleagues, teachers, myself and others. \\
\hline $\begin{array}{l}\text { Tasks accomplished in } \mathrm{E} \text { - } \\
\text { learning }\end{array}$ & $\begin{array}{l}\text { Accessing learning contents, Watching educational videos, Chatting for } \\
\text { learning, playing educational games, social networking for learning (say } \\
\text { educational forums, discussion boards), assignment preparation, } \\
\text { communication (say email, text messages) with colleagues and teachers, } \\
\text { accessing dictionary, reading E-books, downloading ( say games, } \\
\text { educational software), up loading (say documents), taking quiz, recording } \\
\text { of lectures, taking photographs of slides and video conferencing. }\end{array}$ \\
\hline \multicolumn{2}{|l|}{ Mobile devices as learning } \\
\hline $\begin{array}{l}\text { Ease of use of mobile devices } \\
\text { for learning }\end{array}$ & $\begin{array}{l}\text { Learner can use learning material at any place, learner can use learning } \\
\text { material at any time, creation of learning materials is easy, sharing of } \\
\text { learning materials is easy, learning contents are in multiple formats (e.g. } \\
\text { audio, video, document), learning content can be used for practical } \\
\text { courses, the learning contents are compatible with different mobile } \\
\text { operating systems (android, i phones etc.), end user support exists in the } \\
\text { form of chat, and educational forums, people deprived of education can } \\
\text { learn and people with special needs can learn (e.g. physically challenged). }\end{array}$ \\
\hline $\begin{array}{l}\text { Suitability of mobile devices } \\
\text { for learning }\end{array}$ & $\begin{array}{l}\text { Using mobile devices for learning is easy, mobile devices can be easily } \\
\text { operated, learners has knowledge how to use mobile devices for learning, } \\
\text { mobile device use as a learning tool requires training, mobile device use } \\
\text { as a learning tool requires planning, the average screen size of mobile } \\
\text { devices is appropriate for learning, the ordinary memory storage capacity } \\
\text { of mobile devices is good enough for learning, the moderate power } \\
\text { capacity of mobile devices is sufficient for learning, the accessible internet } \\
\text { connectivity is good for learning in Oman and the available mobile device } \\
\text { infrastructure can be used for learning in Oman }\end{array}$ \\
\hline $\begin{array}{l}\text { Interaction and Collaboration } \\
\text { learning using mobile devices }\end{array}$ & $\begin{array}{l}\text { Mobile devices facilitates one to one Learning, mobile devices facilitates } \\
\text { learning in groups, and tracking the progress is easy, evaluation can occur } \\
\text { instantly and interface design are user friendly. }\end{array}$ \\
\hline Enjoyments & $\begin{array}{l}\text { learning with the help of } \\
\text { help of Educational Apps }\end{array}$ \\
\hline
\end{tabular}




\begin{tabular}{|c|c|}
\hline devices for learning & is pleasing and learning using a mobile device is not boring. \\
\hline $\begin{array}{l}\text { Economic feasibility of } \\
\text { learning using mobile devices }\end{array}$ & $\begin{array}{l}\text { A mobile device cost is affordable, internet subscription fee is } \\
\text { manageable, learning contents are economical (say E-book, discussion } \\
\text { forums), learning contents can be used as many times as desired, M- } \\
\text { learning requires financial support from the College, Financial support } \\
\text { from the Government is desired for M-learning and Reduction in the } \\
\text { overall learning expenditure. }\end{array}$ \\
\hline $\begin{array}{l}\text { Social feasibility of learning } \\
\text { using mobile devices }\end{array}$ & $\begin{array}{l}\text { Develops human values, develops trust between students and teachers, } \\
\text { reduces use of paper so it friendly to environment, learning contents are } \\
\text { available according to the local culture, learning contents are available } \\
\text { according to the users need and learning contents are available in } \\
\text { different languages }\end{array}$ \\
\hline $\begin{array}{l}\text { Willingness to adopt mobile } \\
\text { devices for learning }\end{array}$ & Yes, No \\
\hline
\end{tabular}

Athabasca University (a) ( $)$ 